\title{
A Intervenção dos Músicos do Elo em um Centro de Hemodiálise. uma Experiência Humanizadora de Êxito.
}

\author{
Almeida, Fernando Antonio de; Hoffmann, Thiago dos Reis; Fabro, Wilson Brisola; \\ Camargo, Leilianne Teixeira; Flusser, Victor; Santoro, Luiz Fernando; Almeida, \\ Fernando Antonio de
}

Faculdade de Ciências Médicas e da Saúde da PUC/SP, Campus Sorocaba - faalmeida@globo.com

\begin{abstract}
INTRODUÇÃO: a doença renal crônica (DRC) é um problema de saúde pública no Brasil e no mundo, apresentando altos índices de morbidade e mortalidade, perdas substanciais de anos de vida produtiva e gastos para o sistema de saúde. em seu estadio terminal a vida só é mantida por terapia renal substitutiva (TRS). Hoje há no Brasil mais de 95.000 indivíduos em TRS, 90\% deles submetidos a três sessões semanais de hemodiálise (HD). Além dos sintomas próprios da doença, os indivíduos com DRC convivem com inúmeras adaptações pessoais, familiares e sociais, comprometendo o estado emocional e a qualidade de vida (QV). a doença incurável e a proximidade da morte produzem complexos transtornos psicológicos, num ciclo de acontecimentos negativos que permeiam suas vidas e de seus familiares. a proposta de trabalho dos Músicos do Elo em ambiente hospitalar é fundamentalmente humanizadora e enriquece os cuidados dirigidos aos pacientes, familiares e funcionários. Os músicos fazem um curso de especialização de um ano onde são capacitados a entender e respeitar as características do ambiente hospitalar onde atuam. por ser uma experiência exitosa em vários centros europeus de cuidados à saúde, entendemos que a atuação dos Músicos do Elo viria ao encontro das necessidades dos pacientes em HD. OBJETIVOS: Avaliar as repercussões da presença dos Músicos do Elo durante uma das sessões semanais de HD sobre a sensação subjetiva de bem estar dos pacientes, sobre a QV e parâmetros de depressão. MÉTODOS: Participaram do estudo 24 pacientes que realizam hemodiálise há mais de 6 meses. Destes, 12 formaram o grupo controle (sem intervenção) e 12 pacientes sofreram a intervenção dos Músicos do Elo, por 5 meses, nas sessões regulares de HD aos sábados. Avaliamos a QV pelo questionário Kidney Disease and Quality of Life - Short Form (KDQOL-SF ${ }^{\mathrm{TM}}$ ) - v.1.3 e o estado de depressão pela escala de Hamilton. Foi aplicado aos pacientes um questionário aberto para avaliar os efeitos da intervenção e os resultados submetidos à análise temática e à técnica de Análise do Discurso do Sujeito Coletivo (Lefrève). RESULTADOS: Encontramos excelente receptividade, participação e comprometimento dos pacientes e engajamento dos funcionários ao trabalho dos Músicos do Elo. Houve melhora da QV global (59 vs 65, onde zero é o pior possível e 100 o melhor possível) e, em particular, nos seguintes domínios: disposição para o trabalho (17 vs 33), percepção de encorajamento do pessoal técnico do centro (67 vs 92), limitações emocionais (47 vs 72) e sono (62 vs 69). no grupo intervenção o número de pacientes com critérios de depressão moderada/grave reduziu de 10/12 para 6/12 ( $<0,05$, X2). CONCLUSÕES: a intervenção foi muito bem aceita por pacientes e funcionários do centro de hemodiálise. a presença dos músicos afasta os pacientes da condição de preocupação, ansiedade e dependência da máquina e resgata sentimentos positivos e harmoniosos de experiências anteriores, criando uma atmosfera de trabalho acolhedora e de confiança. Esta ação humanizadora no ambiente da hemodiálise resulta em melhora das condições psicológicas, da percepção de bem estar e da QV dos pacientes. Veja o vídeo com a atuação dos músicos em: http://vimeo.com/43105902
\end{abstract}

Almeida, Fernando Antonio de; Hoffmann, Thiago dos Reis; Fabro, Wilson Brisola; Camargo, Leilianne Teixeira; Flusser, Victor; Santoro, Luiz Fernando; Almeida, Fernando Antonio de. A Intervenção dos Músicos do Elo em um Centro de Hemodiálise. uma Experiência Humanizadora de Êxito.. In: Anais do Congresso Internacional de Humanidades \& Humanização em Saúde [= Blucher Medical Proceedings, num.2, vol.1]. São Paulo: Editora Blucher, 2014. ISSN 23577282

DOI 10.5151/medpro-cihhs-10192 